\title{
Cryoglobulinaemia induced digital gangrene in a case of hepatitis C
}

\author{
Amna Abdel-Gadir, ${ }^{1}$ Ketan Patel, ${ }^{2}$ Simon W Dubrey ${ }^{1}$ \\ ${ }^{1}$ Department of Cardiology, Hillingdon Hospital, Uxbridge, UK \\ ${ }^{2}$ Departmet of Haematology, Hillingdon Hospital, Uxbridge, UK \\ Correspondence to Simon W Dubrey, simon.dubrey@thh.nhs.uk
}

\section{DESCRIPTION}

A 65-year-old woman presented with severe pain in the fingers of both hands (figure 1).

The patient was diagnosed with hepatitis $\mathrm{C}$ virus (HCV), following blood transfusion 30 years ago, and had developed the associated pathologies of cirrhosis and cryoglobulinaemia. Over the past 7 years, she had required multiple hospital admissions to treat associated complications. These consisted of renal impairment, hypertension, restrictive cardiomyopathy, ascites, severe peripheral oedema, neuropathy and skin ulceration. Her digital ischaemia was treated with opiate analgesia, calcium channel blockers and repeated prostacyclin infusions with limited benefit aside from pain relief.

$\mathrm{HCV}$ is primarily associated with type II mixed cryoglobulinaemia. It is reported that $40-60 \%$ of patients with HCV infection have cryoglobulins. ${ }^{1}$ However, in only $5-10 \%$ of cases will a cryoglobulinaemia induced vasculitis and/or intravascular immune complex depositions occur.
The prevalence is increased in patients with long standing $\mathrm{HCV}$ infection, cirrhosis and in females. The incidence rate for haematological cryoglobulinaemia is quoted to be $2.3-3.0 \%$ per year, in which around $0.3 \%$ per year develop a vasculitic syndrome, like our patient. ${ }^{2}$ An important feature is that in many cases the extrahepatic manifestations of $\mathrm{HCV}$ infection can occur in patients without features of an overt liver disease. ${ }^{1}$

$\mathrm{HCV}$ infection, particularly when chronic and in the presence of cryoglobulinaemia, is frequently a devastating multisystem disease. ${ }^{3}$ Around $10 \%$ of patients with chronic HCV infection may also go on to develop a malignant B cell lymphoma.

Our patient passed away $24 \mathrm{~h}$ after this photograph was taken.

Competing interests None.

Patient consent Obtained.

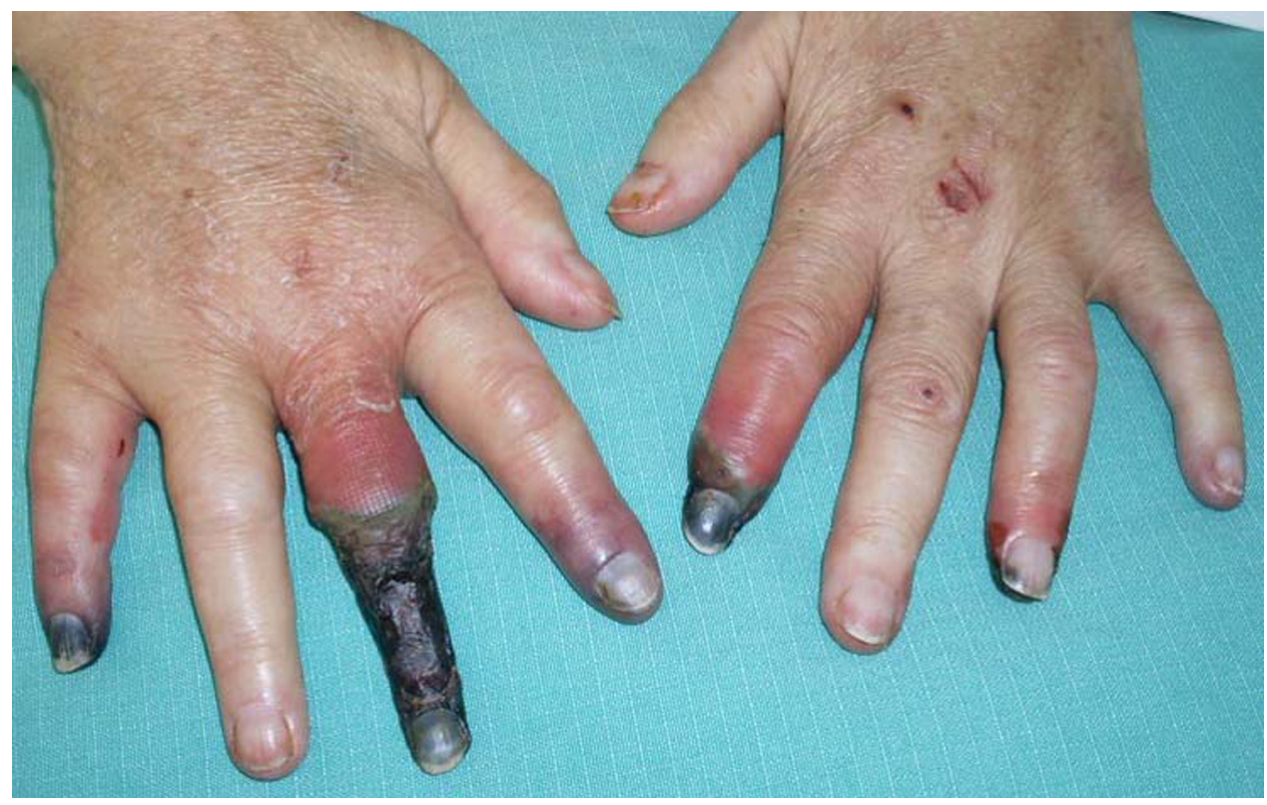

Figure 1 Hands of the patient with cryoglobulin-induced gangrene. 


\section{BMJ Case Reports}

\section{REFERENCES}

1. Saadoun D, Landau DA, Calabrese LH, et al. Hepatitis C-associated mixed cryoglobulinaemia: a crossroad between autoimmunity and lymphoproliferation. Rheumatology (Oxford) 2007;46:1234-42.

2. Viganò $\mathbf{M}$, Lampertico $\mathrm{P}$, Rumi MG, et al. Natural history and clinical impact of cryoglobulins in chronic hepatitis C: 10 -year prospective study of 343 patients. Gastroenterology 2007;133:835-42.
3. Stefanova-Petrova DV, Tzvetanska AH, Naumova EJ, et al. Chronic hepatitis $C$ virus infection: prevalence of extrahepatic manifestations and association with cryoglobulinemia in Bulgarian patients. World J Gastroenterol 2007;13:6518-28

This pdf has been created automatically from the final edited text and images.

Copyright 2010 BMJ Publishing Group. All rights reserved. For permission to reuse any of this content visit

http://group.bmj.com/group/rights-licensing/permissions.

BMJ Case Report Fellows may re-use this article for personal use and teaching without any further permission.

Please cite this article as follows (you will need to access the article online to obtain the date of publication)

Abdel-Gadir A, Patel K, Dubrey SW. Cryoglobulinaemia induced digital gangrene in a case of hepatitis C. BMJ Case Reports 2010;10.1136/bcr.10.2010.3439, date of publication

Become a Fellow of BMJ Case Reports today and you can:

Submit as many cases as you like

Enjoy fast sympathetic peer review and rapid publication of accepted articles

Access all the published articles

Re-use any of the published material for personal use and teaching without further permission

For information on Institutional Fellowships contact consortiasales@bmjgroup.com

Visit casereports.bmj.com for more articles like this and to become a Fellow 